\title{
DEVELOPING A FRAMEWORK FOR CHARACTERIZING RECREATIONAL POTENTIAL OF FOREST AREAS USING WEIGHTED CRITERIA ANALYSIS
}

\author{
Edgars Jūrmalis, Zane Lībiete \\ Latvian State Forest Research Institute 'Silava', Latvia \\ edgars.jurmalis@silava.lv
}

\begin{abstract}
Forests offer a wide variety of ecosystem services, including cultural or recreational services. In that sense, stateowned forest lands hold the biggest responsibility to acknowledge and provide these services, where it is economically and ecologically viable. Suitability analysis has been extensively used to provide information on species conservation measures, and it is possible to apply similar techniques for potential supply of recreational services. A simple weighted overlay analysis was conducted to locate forest land areas most suitable for potential recreational activities. Several criteria were selected for the analysis, including forest stand parameters such as forest stand age, forest stand type and species, topographical diversity and remoteness. Basis for the weighting of the selected criteria were obtained from the social surveys, previous research work done in Latvia and the Baltics, and European scale scientific data on recreation preferences. The analysis showed that $20 \%$ of the total model area analyzed provide substantially high recreation potential. Furthermore, these preliminary data can be used for surveying and facilitating community involvement processes. Local tourism and nature leisure activities can be promoted by exploring possibilities of alternative forestry planning options, utilizing such multifunctional assessments of recreational supply.
\end{abstract}

Key words: forest recreation, spatial planning, suitability analysis, weighted overlay.

\section{Introduction}

Forest ecosystem services have been a hot topic in recent research, concerning both multitude of provided services and potential trade-offs between different ecosystem service groups. One such research area deals with forest recreational (cultural) services (Hermes et al., 2018; Lankia et al., 2015). As a nontangible service, recreational potential and demand can be difficult to quantify in terms of spatial planning and managing resource harvests.

State forestlands in Latvia are managed on a 'three-pillar' basis - considering economic, social and ecological goals. There is extensive work done in the field of ecological habitat conservation and smart planning using landscape ecological approaches, although one could wish for clearer methodology and selection criteria related to the delineation of recreational areas (defined as 'Eco forests for recreational use'). Currently, approximately $3341 \mathrm{~km}^{2}$ of state forest area is managed with this goal (LVM Geo, 2019). As a basis of multifunctional forestry, multiple services and resources should be valued and mapped, to provide a wider basis for decision making on different planning scales, and to avoid or diffuse possible conflicts (Pohjanmies et al., 2017).

It is clear that not all forest landscapes can offer the same recreational quality, and there are several parameters or criteria that can influence the 'appeal' of certain forest area for recreation both from a planning standpoint and from a visitor's standpoint (Nielsen, Heyman, \& Richnau, 2012; Ridding et al., 2018). In Europe, research results on recreational and landscape preferences can be diverse based on regional and cultural differences (mixed, higher density forest stands in Central Europe or less dense coniferous forests in Scandinavia) (Ciesielski \& Stereńczak, 2018). In Latvia, a country that is located in the boreonemoral forest zone, the main factor for determining site preference seems to be forest stand density and the presence of a strong understory (negative influence) (Donis, 2012). Criteria such as complexity, mistery or familiarity can also be drawn from photo stories, and results of such research in the Baltics also point towards a preference for coniferous, older stands to have higher recreational values (Hansson et al., 2012). However, due to the fact that complex, emotional landscape preference features are hard to quantify, forest stand characteristics were the main parameters used to develop criteria for recreational provision for the purposes of this study.

The main goal of this research was to develop a method that delivers useful spatial information, ready to be applied for identifying and managing potential recreational sites. It is important to note that this research focuses on the supply aspect of the selected ecosystem service, not explicitly covering the demand. Recreational demand can be determined by using surveys, Delphi or public mapping methods. Landscape preferences in Latvia have been determined in earlier research works using large sample ( $\mathrm{n}=\sim 1000)$ surveys, which serve as an important basis for developing the recreational site criteria (Donis, unpublished). The subjectivity of recreational services makes it difficult to determine whether expert or public opinions are more crucial to determine recreation site quality and willingness to use this ecosystem service. This research can be continued fluidly by creating picture surveys or conducting onsite interviews, for confirmation and validation of supply- demand matches or mismatches. 


\section{Materials and Methods}

The basic operational steps for the developed framework follow this scheme: collection of available geospatial or other data, evaluation of each data layer (criteria), reclassification of each criteria, overall weighting of each criteria and final output result (which can also be reclassified).

Using forest stand inventory data, the following criteria were chosen to represent the basic, preliminary features of recreational potential - forest stand age, forest stand density, forest stand type and dominating tree species. The motivation for the choice of these specific criteria was based on the previous research that has demonstrated that these features are among the most important when assessing the suitability of forest areas for recreation (mainly from the aesthetic point of view). These criteria were then used to identify unsuitable or unlikely areas for forest recreation activities and to locate areas with potentially high recreational values, based on preliminary analysis of literature, national survey and expert data, with the goal to find optimal recreational preference. Each site type was assigned a criterion value based on its most common expected characteristics (Table 2). The criteria were valued on a scale of 1 (low value) to 5 (high value) points, and further weighted using criteria weights (in this analysis the focus was on the forest stand parameters, rather than on the other criteria) (Table 1). It was assumed that every forest stand provides recreational opportunities to a certain level, but selective criteria like the occurrence of pine as a dominating species and older forest stands, for example, had higher point values. Literature sources varied slightly on several criteria, but information of broader preferences were analyzed in Latvian context, provided by the national survey data and previous research works. The three other criteria, based on abiotic and spatial distribution aspects, were used from other data sources. The proposed framework can be modified with additional criteria, based on the available data.

For the purpose of demonstrating the proposed method of estimating potential recreation values, two state forest areas (Nicas and Grobinas forest planning districts) were used as the study sites (the total area of $1695,4 \mathrm{~km}^{2}$ ). The combined forest area

\section{Criteria used for the evaluation of recreational potential of forest areas}

Table 1

\begin{tabular}{|c|c|c|c|}
\hline Criteria & Value scale ( 1 - lowest, 5 - highest $)$ & Literature & $\begin{array}{l}\text { Criteria } \\
\text { weight }\end{array}$ \\
\hline $\begin{array}{l}\text { Forest stand age class* (of the } \\
\text { dominant species; based on } \\
\text { forest inventory results) }\end{array}$ & $\begin{array}{c}\text { Young stands, middle-aged stands }-2 \text { points } \\
\text { Premature, mature stands }-5 \text { points } \\
\text { Overmature stands }-4 \text { points }\end{array}$ & $\begin{array}{l}\text { Hansson et al., 2012; } \\
\text { Donis, } 2013\end{array}$ & 2 \\
\hline $\begin{array}{l}\text { Forest stand type (defines } \\
\text { stand composition and } \\
\text { undergrowth) (Table 2) }\end{array}$ & $\begin{array}{l}\text { Dry or drained, mineral soil based forest stands with } \\
\text { less undergrowth }-5 \text { points } \\
\text { Wet, mineral or organic soil based forest stands - } \\
\quad 3 \text { points } \\
\text { Drained forest types with a high productivity/dense } \\
\text { undergrowth }-2 \text { points }\end{array}$ & $\begin{array}{l}\text { Donis, 2013; } \\
\text { Donis, unpublished; } \\
\text { Hansson et al., } 2012\end{array}$ & 2 \\
\hline Forest stand density & $\begin{array}{c}\text { Stand density } 1 \text { to } 3-3 \text { points } \\
\text { Stand density } 3 \text { to } 7-5 \text { points } \\
\text { Stand density } 7 \text { to } 9-4 \text { points } \\
\text { Stand density } 10 \text { and above }-1 \text { point } \\
\end{array}$ & Edwards et al., 2012 & 2 \\
\hline $\begin{array}{l}\text { Dominating tree species (can } \\
\text { include mixed stands) }\end{array}$ & $\begin{array}{c}\text { Pine }-5 \text { points } \\
\text { Other tree species }-3 \text { points }\end{array}$ & $\begin{array}{l}\text { Hansson et al., 2012; } \\
\text { Donis, } 2013\end{array}$ & 2 \\
\hline $\begin{array}{c}\text { Topographical diversity } \\
\text { (calculated from DEM } 20 \mathrm{~m} \\
\text { using Jenness, 2002) } \\
\end{array}$ & $\begin{array}{c}\text { No topographical diversity }-0 \text { points } \\
\text { Some topographical diversity }-2 \text { points } \\
\text { Noticeable topographical diversity }-3 \text { points } \\
\end{array}$ & $\begin{array}{l}\text { Komossa et al., } \\
\text { 2018; Weyland \& } \\
\text { Laterra, } 2014 \\
\end{array}$ & 1 \\
\hline $\begin{array}{c}\text { Accessibility from local road } \\
\text { networks }\end{array}$ & $\begin{array}{c}500 \mathrm{~m}-5 \text { points } \\
\sim 500 \mathrm{~m} \text { to } 2 \mathrm{~km}-4 \text { points } \\
3 \mathrm{~km} \text { and above }-2 \text { points } \\
\end{array}$ & Lībiete et al., 2018 & 1 \\
\hline $\begin{array}{l}\text { Proximity to current } \\
\text { recreational areas } \\
\text { (connectivity) }\end{array}$ & $\begin{array}{c}>1 \mathrm{~km}-5 \text { points } \\
1-5 \mathrm{~km}-4 \text { points } \\
6-10 \mathrm{~km}-3 \text { points } \\
11 \text { and above }-2 \text { points }\end{array}$ & Authors' suggestion & 1 \\
\hline
\end{tabular}

* Age class interval for conifers and hardwoods is 20 years, for softwoods - 10 years, for especially fast-growing trees, e.g., grey alder or willow -5 years. For conifers and hardwoods the division is the following: age classes I and II - young stand, age class III - middle-aged stand, age class IV - premature stand, age class V and VI - mature stand, age class VII+ - overmature stand. For softwoods division is the following: age classes I and II - young stand, age class III and IV middle-aged stand, age class V - premature stand, age class VI and VII - mature stand, age class VIII + - overmature stand. 
Values of individual site types for recreational provision

\begin{tabular}{|c|c|c|c|c|c|}
\hline $\begin{array}{c}\text { Forest growth/ } \\
\text { biophysical } \\
\text { conditions and } \\
\text { criteria value points }\end{array}$ & Dry forests & Wet forests & Mire forests & $\begin{array}{c}\text { Drained mineral } \\
\text { based }\end{array}$ & $\begin{array}{c}\text { Drained organic } \\
\text { based }\end{array}$ \\
\hline \multirow{6}{*}{ Forest type } & $\begin{array}{l}\text { Cladinoso- } \\
\text { callunosa } \\
\text { (5 points) }\end{array}$ & $\begin{array}{l}\text { Callunoso- } \\
\text { sphagnosa } \\
\text { (5 points) }\end{array}$ & $\begin{array}{l}\text { Sphagnosa } \\
\text { (3 points) }\end{array}$ & $\begin{array}{l}\text { Callunosa mel. } \\
\text { (5 points) }\end{array}$ & $\begin{array}{l}\text { Calluna turf. Mel. } \\
\text { (3 points) }\end{array}$ \\
\hline & $\begin{array}{l}\text { Vacciniosa } \\
\text { (5 points) }\end{array}$ & $\begin{array}{l}\text { Vaccinioso- } \\
\text { sphagnosa } \\
\text { (5 points) }\end{array}$ & $\begin{array}{c}\text { Caricoso- } \\
\text { phragmitosa } \\
\text { (2 points) }\end{array}$ & $\begin{array}{l}\text { Vacciniosa mel. } \\
\quad(5 \text { points })\end{array}$ & $\begin{array}{l}\text { Vacciniosa turf. } \\
\text { mel. (3 points) }\end{array}$ \\
\hline & $\begin{array}{l}\text { Myrtillosa } \\
\text { (5 points) }\end{array}$ & $\begin{array}{l}\text { Myrtilloso- } \\
\text { sphagnosa } \\
\text { (3 points) }\end{array}$ & $\begin{array}{c}\text { Dryopterioso- } \\
\text { caricosa (2 points) }\end{array}$ & $\begin{array}{l}\text { Myrtillosa mel. } \\
\text { (3 points) }\end{array}$ & $\begin{array}{l}\text { Myrtillosa turf. } \\
\text { mel. (3 points) }\end{array}$ \\
\hline & $\begin{array}{l}\text { Hylocomiosa } \\
\text { (5 points) }\end{array}$ & $\begin{array}{l}\text { Myrtilloso- } \\
\text { polytrichosa } \\
\text { (3 points) }\end{array}$ & $\begin{array}{l}\text { Filipendulosa } \\
\text { (2 points) }\end{array}$ & $\begin{array}{l}\text { Mercurialiosa } \\
\text { mel. (2 points) }\end{array}$ & $\begin{array}{l}\text { Oxalidosa turf. } \\
\text { mel. (2 points) }\end{array}$ \\
\hline & $\begin{array}{l}\text { Oxalidosa } \\
\text { (2 points) }\end{array}$ & $\begin{array}{l}\text { Dryopteriosa } \\
\text { (2 points) }\end{array}$ & & & \\
\hline & $\begin{array}{l}\text { Aegopodiosa } \\
\text { (2 points) }\end{array}$ & & & & \\
\hline
\end{tabular}

of both districts potentially provides close-proximity, rural forest recreational services for regional capital Liepaja, as well as for several smaller towns and villages. Forest stand inventory data for the study area was combined with open source data provided by the LVM GEO platform and GIS Latvia 10.2 (GIS Latvija 10.2 , 2019) open source database. In this analysis, only state forests were taken into account, excluding privately owned and strictly urban forests. State forests dominate in the study area. Digital elevation data from LGIA (10 m step) was used to determine topographical diversity as a criterion for recreational potential. Data on micro reserve habitat areas was used initially, but in the final spatial outputs these areas were omitted due to a very small coverage. All data was converted and used in raster format with the cell size of $100 \mathrm{~m}$.

Using overlay criteria analysis (Weighted Sum tool) in ArcMap 10.x, the valued and reclassified data layers/criteria were weighted using the provided criteria weight value (see Table 1), summed together in a final data layer. The analysis values were further reclassified on a $1-5$ scale. The final values of the recreational potential indicator are as follows -1 being the lowest value for recreational potential and 5 being the highest. No data values (including mires and other land categories which are not a part of this analysis) and private forest areas were classified as 0 in this case.

\section{Results and Discussion}

As seen in the final output of the analysis (Figure 1), the spatial distribution of high or low recreational potential varies. Already existing recreational sites along the Bārta river and in the established nature parks or recreational infrastructure objects that are already in place coincide with some high recreational potential value areas as derived from the analysis, but since proximity of the existing recreation sites is one of the proposed criteria, these areas are not used for verification of the model results. Areas with lower recreational potential are identified north of Grobina and below Jěčupe river, which could be the result of specific forest stand types and management, as well as a lack of existing recreational infrastructure. From the planning standpoint, such results using the proposed framework could indicate that areas with high values may be further investigated and planning solutions may be implemented, if there are no existing recreational forest areas in the area, or if the model outputs match with public opinion or other sources of information for the planner (e.g., Latvia's State Forests or municipalities). Overall, $20 \%$ of the total valued forest area (excluding mires, clear-cuts and other areas) were determined to have very high recreational potential, while medium or average potential was assigned to $59 \%$ of the total valued area. Using the approach, reclassification of the model results can be done to identify the highest possible values and to avoid counting 'average' areas as high value ones. The methodological framework, as shown in the case example, is applied on a regional (municipal) planning scale, but it can be applied to various scales, by adjusting raster analysis cell sizes (both large scale country assessments and detailed, small scale watershed analysis could be conducted 
$\Delta_{N}$

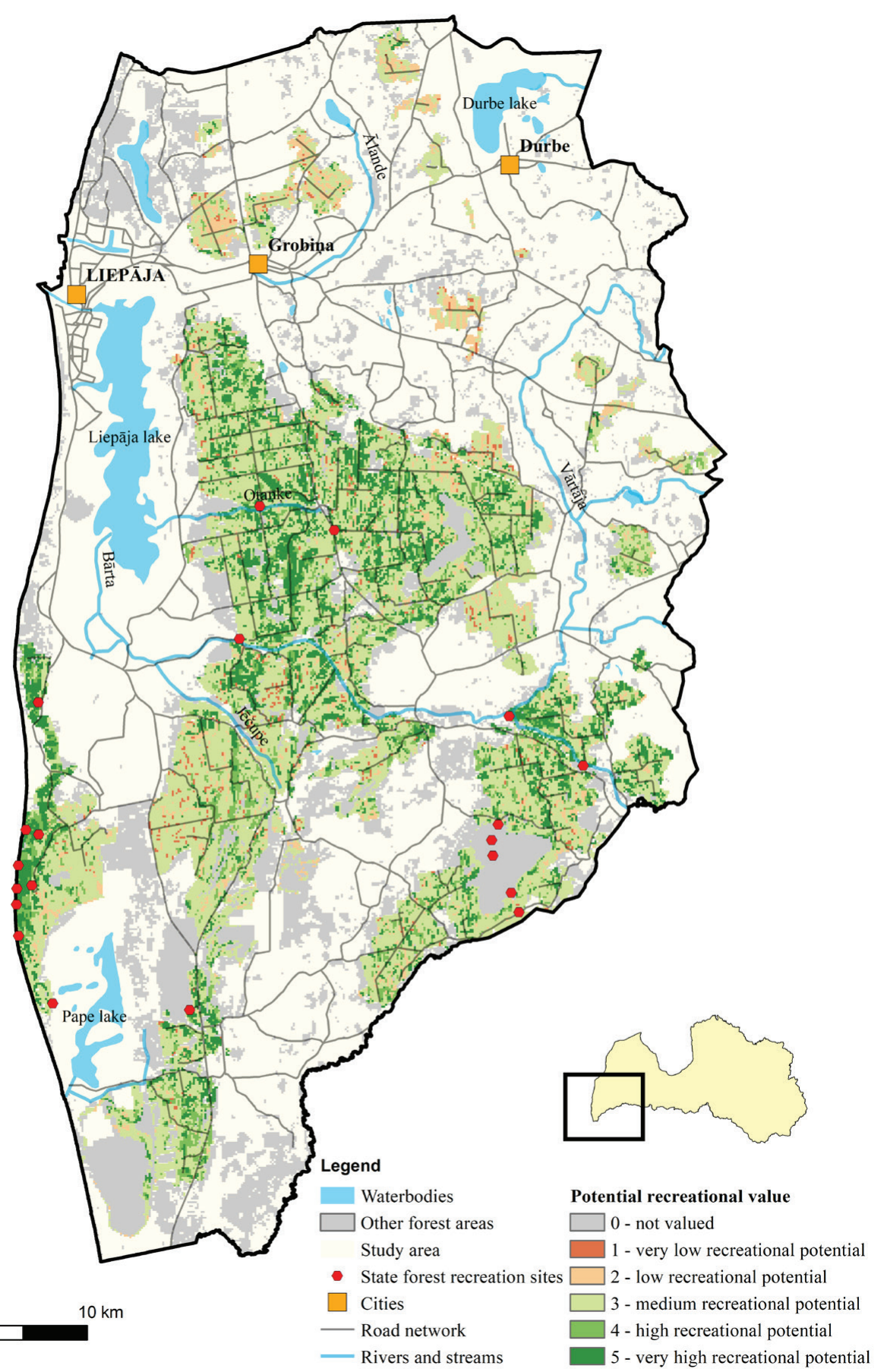

Figure 1. Demonstration of the results of the proposed method for assessing recreational potential in state forest areas.

using the framework). Available data for small-scale analysis might be constricted for criteria concerning topographical analysis (quality and resolution of available DEM), but forest inventory databases (which is the main aspect of this proposed framework) in Latvia have a reasonably detailed geospatial data resolution, which could be supplemented by remote sensing.
Multiple studies have been conducted on a European scale, and some include the weighted overlay aspects as used in this analysis (Komossa et $a l ., 2018)$. The scale of recreational potential research is often either on a small, urban scale or covering entire pan-European region. Multiple aspects and criteria used in this research involve synthesizing knowledge of different forest preferences from other regions of 
Europe - both Central and Northern (Scandinavian), which creates more uncertainty for the results and practical applications. Although no survey methods were applied in this analysis, the results can be considered as a basic framework, which can be further detailed and adjusted for different types of recreational groups (for example, recreational foragers, mountain bikers, hikers or wildlife photographers). The criteria method is a viable solution from a GIS standpoint, as it gives flexible space to easily change criteria values and weights - analysis could be conducted to focus more on accessibility and topographical factors, for example, rather than on forest stand features as in this study. For example, extreme forest hikers could have a higher subjective value for rough terrain compared to bird watchers or casual hikers. Accessibility could also have a more complex approach, as demonstrated in Paracchini et al., 2014, where high value recreation areas could have both remoteness and urban neighborhood access values implemented in a matrix scale. The results of this analysis can be spatially shown as heterogeneous gradient values over a single land cover type (as compared to single values being applied to entire forest compartments or other planning units). Although forest compartment borders and delineations still show in the final results, the nature of distance, topographical and connectivity criteria add dynamic values to the results, which are mostly not related to the forest compartment spatial borders. The proposed method of assessing forest recreation potential can have some drawbacks, including uncertainty of the proposed criteria values and open-ended discussions on criteria importance for forest recreation preferences and uncertainty of accuracy of forest inventory data (which needs to be tested on field or by using remote sensing data). Aspects of recreational stress on ecosystems is overlooked in this version of the framework, especially in the case of topographical diversity, as too much recreational demand in diverse terrain areas could cause erosion processes. To further develop and implement the framework for local and regional scale assessments of forest recreation provision, expert and public surveys should be conducted to assess the subjective preferences and to achieve more accurate representations for criteria scaling, as opposed to only using literature sources. Criteria, such as, population density or distance from the population centers, should be added to have a full demand-supply flow of recreational potential. The framework from a GIS standpoint also allows to assess the potential trade-offs between various recreational groups and preferences, and trade-offs between forestry operations (by evaluating forest harvest provision services in the same area), where multiple recreation or harvest analysis maps are combined and analyzed in raster calculator or other tools.

\section{Conclusions}

1. At the current stage, the suggested approach offers a flexible way for preliminary assessment of recreational potential in forest areas.

2. Diversified criteria and inputs from expert or public sources are needed to increase the reliability of the approach, ensuring more accurate analysis results.

3. The subjectivity of recreational values is difficult to avoid during any related analysis, although forest planning can still include such results to support decision making processes in both forestry and recreational infrastructure planning operations.

4. The standpoint of multiple preference groups can be involved in such framework, by applying different sets of criteria for each type of recreational groups.

\section{Acknowledgments}

The study was carried out within the framework of the Latvian State Forest Research Institute 'Silava' and JSC 'Latvia's State Forests' collaboration research programme 'The impact of forest management on ecosystem services provided by forests and related ecosystems'.

\section{References}

1. Ciesielski, M., \& Stereńczak, K. (2018). What do we expect from forests? The European view of public demands. Journal of Environmental Management, 209, 139-151. DOI: 10.1016/j.jenvman.2017.12.032.

2. Donis, J. (2013). Latvijas meža resursu ilgtspējīgas, ekonomiski pamatotas izmantošanas un prognozēšanas modelu izstrāde (Latvian forest resource sustainable use models). Retrieved February 2, 2019, from http:// silava.lv/userfiles/file/Projektu\%20parskati/2013_Donis_MAF.pdf. (in Latvian)

3. Edwards, D., Jay, M., Jensen, F., Lucas, B., Montagné, C., Peace, A., \& Weiss, G. (2012). Public preferences for structural attributes of forests: Towards a pan-European perspective. Forest Policy and Economics, 19, 12-19. DOI: 10.1016/j.forpol.2011.07.006.

4. GIS Latvija 10.2 (2018). Open-source geodata. Retrieved February 2, 2019, from http://www.envirotech. lv/lv/aktualitates/gis-latvija-10-2/.

5. Hansson, K., Külvik, M., Bell, S., \& Maikov, K. (2012). A preliminary assessment of preferences for Estonian natural forests. Baltic Forestry, 18(2), 299-315. 
6. Hermes, J., Van Berkel, D., Burkhard, B., Plieninger, T., Fagerholm, N., von Haaren, C., \& Albert, C. (2018). Assessment and valuation of recreational ecosystem services of landscapes. Ecosystem Services, 31, 289-295. DOI: 10.1016/j.ecoser.2018.04.011.

7. Jenness (2002). Surface Areas and Ratios from Elevation Grid (surfgrids.avx) extension for ArcMap 3.x, v. 1.2. Jenness Enterprises. Retrieved February 15, 2019, from http://www.jennessent.com/arcview/surface areas.htm.

8. Komossa, F., van der Zanden, E.H., Schulp, C.J.E., \& Verburg, P.H. (2018). Mapping landscape potential for outdoor recreation using different archetypical recreation user groups in the European Union. Ecological Indicators, 85(May 2017), 105-116. DOI: 10.1016/j.ecolind.2017.10.015.

9. Lankia, T., Kopperoinen, L., Pouta, E., \& Neuvonen, M. (2015). Valuing recreational ecosystem service flow in Finland. Journal of Outdoor Recreation and Tourism, 10, 14-28. DOI: 10.1016/J.JORT.2015.04.006.

10. Lībiete, Z., Bārdule, A., Kḷaviņš, I., Kalvīte, Z., \& Jūrmalis, E. (2018). Mežsaimniecības ietekme uz meža un saistīto ekosistēmu pakalpojumiem (Foresty effects on ecosystem services). Retrieved January 24, 2019, from http://silava.lv/userfiles/file/Projektu\%20parskati/2017_Libiete_LVM_EP_bezapt.pdf. (in Latvian)

11. LVM GEO (2019). Spatial data on state forest resources. Retrieved February 21, 2019, from https://www. lvmgeo.lv/en/maps.

12. Nielsen, A.B., Heyman, E., \& Richnau, G. (2012). Liked, disliked and unseen forest attributes Relation to modes of viewing and cognitive constructs. Journal of Environmental Management, 113, 456-466. DOI: 10.1016/j.jenvman.2012.10.014.

13. Paracchini, M.L., Zulian, G., Kopperoinen, L., Maes, J., Schägner, J.P., Termansen, M., ... Bidoglio, G. (2014). Mapping cultural ecosystem services: A framework to assess the potential for outdoor recreation across the EU. Ecological Indicators, 45, 371-385. DOI: 10.1016/J.ECOLIND.2014.04.018.

14. Pohjanmies, T., Triviño, M., Le Tortorec, E., Salminen, H., \& Mönkkönen, M. (2017). Conflicting objectives in production forests pose a challenge for forest management. Ecosystem Services, 28, 298310. DOI: 10.1016/J.ECOSER.2017.06.018.

15. Ridding, L.E., Redhead, J.W., Oliver, T.H., Schmucki, R., McGinlay, J., Graves, A.R., ... Bullock, J.M. (2018). The importance of landscape characteristics for the delivery of cultural ecosystem services. Journal of Environmental Management, 206, 1145-1154. DOI: 10.1016/j.jenvman.2017.11.066.

16. Weyland, F., \& Laterra, P. (2014). Recreation potential assessment at large spatial scales: A method based in the ecosystem services approach and landscape metrics. Ecological Indicators, 39, 34-43. DOI: 10.1016/J. ECOLIND.2013.11.023. 